\title{
TÜRK BANKACILIK SEKTÖRÜNDE TAHSİLİ GECİKMİŞ ALACAKLAR
}

\author{
Hasan SELCUK I , Adem DARICI \\ 'Marmara Üniversitesi, Hukuk Fakültesi Ekonomi Maliye Bölümü, Doçent Dr. \\ ${ }^{2}$ Denizbank, Kurumsal Pazarlama Uzmant
}

\section{NON PERFORMING LOANS IN THE TURKISH BANKING SECTOR}

Abstract: In the last two decades banking sectors around the world faced number of crises due to lack of stable macroeconomic environment, efficient legislative and administrative framework and sound surveillance/supervision system.

Without any doubt one of the most prominent results of banking crises has been rapid growth of non-performing loans on banks' balance sheets and weakening solvability of corporate sector. The duration and depth of crises can be affected by appropriate solution to this problem.

During financial crises asset management policies, which are mainly defined by classifying bad assets in accordance with quality and liquidity factors, consist of two major implementations; one is voluntary dept restructuring between creditor banks and obligor companies, which is shortly known as London Approach, and the other is utilizing the Asset Management Company alternative.

Asset Management Companies have generally been applied in two types. First application has been known as central Asset Management Companies, which is based on taking over bad loans from all of the banking system. Second type of the Asset Management Companies have been established as an affiliation of each bank and its activity limited with the partner ship bank's non-performing loans.

Out-of dept restructuring workouts were originally implemented in the UK during the 1970s. But this approach gained popularity in the Southeast Asian Crisis. The approach is based on voluntary out-of-court negotiation between banks and companies for restructuring the corporate depths in the light of general principles which were designed before by banks. Corporate sector and governmental bodies.

These two methods can be implemented effectively after financial crises to solve non-performing loans and corporate dept burden. As Asset Management Companies matter of fact these two methods have been used together in Southeast Asian Countries after the crises.

As is known at the end of 2000 and February 20001 Turkish economies experienced two consecutive financial crises. Depending on deterioration of economic conditions after the crises, non-performing loans have sharply increased on bank balance sheets and corporate sector have faced erosion on its solvency.

In the light of these facts. There is Asset Management Companies need to seek Asset Management Companies solution in order to resolve non-performing loans and growing corporate dept burden problems.

Keywords: Non Performing Loans, Asset Management Company, Bad Loans

\section{TÜRK BANKACILIK SEKTÖRÜNDE TAHSİII GECIKMİS ALACAKLAR}

Özet: Bankactlık sektörü yüksek maliyetli krizlerle karşı karșıya gelebilmektedir. Karşılaşılan bankactlık krizlerinin ödemeler sisteminde rahatsizlklara neden olması, krizin sadece bankacıllk sektörü ile sinurlı kalmamastna ve reel sektör üzerinde de olumsuz yansimalar göstermesine neden olmaktadır. Krizin boyut ve niteliğini etkileyebilecek faktörlerin başinda ise ekonomideki tüm birimlerin yükümlülüklerini yerine getirme kabiliyetindeki gerileme gelmektedir. Sonuçta bankacılık sisteminde TGA stoku hızla artarken, sirketler kesiminin kurumsal borçlan ifa edilemez boyuta ulassabilmektedir. Bankactllk sisteminden TGA'tn tasfiye edilmesi ve şirket borçlarnn yapılandırtlarak ekonomideki üretilen kapasitenin korunmasına yönelik temelde iki politika seçeneği bulunmaktadır. Bunlardan ilki bankacılık sisteminden TGA'm belirli bir çerçeve içinde devralinarak bankaların mali yapısinin kisa süre içinde iyilestirilmesine imkan sağlayan Varlık Yönetim Sirketi uygulamast, diğeri ise bankalar ile sirketlerin belirli bir platform üzerinde piyasa mekanizması içinde ve gönüllülük esastna göre bir araya gelerek sirket borclartnin yaptlandırtlmasint sağlayan ve genel olarak Londra Yaklaşımı olarak bilinen kurumsal borc yaptlandirma politikasudvr. Varlk Yönetim Şirketi uygulaması bankacılık sisteminden sorunlu varlıkların alınarak bankalarn asli görevi olan mevduat toplama ve kredi verme fonksiyonuna odaklanmasint sağlamayı amaçlayan bir politika seçeneğidir. Bu șekilde bir yandan bankalartn krizle birlikte zayıflayan mali yaptlart güclendirilirken bir yandan da zaytflayan makroekonomik yapının yoğun sekilde ihtiyac duyduğu kaynak akıș rahatlatilabilmektedir. Finansal bünyesi zaylflayan ve mali yükümlüllüklerini yerine getirmede sikinttlarla karsslasan reel sektör sirketlerine ait borçlartn kredi alacaklist bankalar tarafindan belirli bir çerçeve içinde yeniden yaptlandırtlarak söz konusu şirketlerin varlığınt sürdürebilmesini sağlamaya ve bu şekilde ekonominin üretken kapasitesini korumaya yönelik yaklaşımı ifade eden ve ilk kez ingiltere'de uygulanmast nedeniyle "Londra Yaklaşımı" olarak anlan kurumsal borç yapılandırma politikası ise özellikle Güneydoğu Asya Krizinin ardından önem kazanmışstrr. Diğer ülke uygulamaları dikkate alındiğında TGA stokunun bankacılık sisteminden tasfiyesinde ve kurumsal borçlartn yapılandırtmasında ikili bir yapının kurulmast uygundur. Sonuç olarak dünya tecrübelerinden de görülebileceği gibi TGA'nun ve kurumsal borçların krizlerle zayıflamıs ekonomik yapı üzerinde yaratacă̆z olumsuzluklar ancak bu şekilde izlenecek kapsamli ve birbirini destekleyen politikalarla engellenebilmektedir.

Anahtar Kelimeler: Tahsili Gecikmis Alacaklar, Varlik Yönetim Sirketi, Sorunlu Krediler 


\section{GíRiş}

Dünyanın pek çok bölgesinde etkileri önemli boyutlara ulaşan bankacılık krizlerini ekonominin geneli üzerinde yarattığı olumsuzluklar ve bu olumsuzlukların giderilmesinde katlanılan maliyetlerin ne tür uygulamalarla asgari düzeyde tutulacağı gerek krizlere çözüm bulmaya çalışan karar alıcı otoritelerin gerekse araştırmacıların son dönemlerde üzerinde ağırlıkla durduğu bir konudur.

Genellikle faiz ve kur gibi ekonomideki temel fiyat göstergelerindeki ani dalgalanmalar ile başlayan ve ödemeler sistemini çalışmaz hale getiren bankacılık krizleri, bankacılık sisteminde tahsili gecikmiş alacakların hızla artmasına ve reel sektör şirketlerini de borç ödeme kapasitesinin önemli ölçüde yitirmesine neden olmaktadır. Ortaya çıkan bu tablo ise krizin derinliğinin artmasına ve süresinin uzamasına yol açmaktadır.

Bankacılık sektöründe yaşanan krizlerin sadece bu sektörle sinırlı kalmaması, reel sektör üzerinde de olumsuz yansımalarının olması karar alıcı otoriteleri her iki sektörü birlikte ele alacak çözüm stratejileri bulmaya yöneltmiştir.

Çalışmanın odak noktası diğer ülke uygulamalarında yola çıkarak bankacılık sektöründeki tahsili gecikmiş alacaklar sorununun ne şekilde tasfiye edebileceği ve bu amaçla ülkemizde yapılan uygulamalar oluşturmaktadır.

\section{TAHSILII GECIKMISS ALACAKLAR}

Tahsili gecikmiş alacak veya sorunlu kredi, banka ile borçlu arasındaki geri ödeme anlaşmasının önemli şekilde bozularak tahsilatın gecikmesi ve zarar olasılığının ortaya çıkması olarak tanımlanabilir. Sorunlu kredilerin makul bir süre içinde tam olarak tahsil edebilmesi için bankanın özel ilgi ve takibi gereklidir.

Her bankanın tahsil ettiği kredilerin belli bir oranı sorunlu krediye ve kredi zararına dönüşebilir. Ancak kredi yönetiminde sorumlu yöneticiler sorunlu kredileri kabul edebilir düzeyde tutabilmeli ve kredi kalitesinin bozulması halinde bankayı zarardan koruma beceri ve başarısını gösterebilmelidir [1].

\section{II.1. Sorunlu Kredilerin Nedenleri}

Genellikle sorunlu bir kredinin nedenini tek bir faktöre veya olaya bağlamak mümkün değildir. Kredinin sorunlu hale dönüşmesine katkıda bulanan bir çok nedenden söz edilebilir. Sorunlu bir kredinin nedenlerini saptayabilmek için borçlunun faaliyetlerinin ve banka ile ilişkisinin ayrıntılı bir biçimde incelenmesi gereklidir. $\mathrm{Bu}$ nedenler aşağıda sıralanan üç genel konu çerçevesinde sinuflanabilir [1]:

$$
\begin{aligned}
& \text { a.Firmaya ilişkin nedenler, } \\
& \text { b.Çevresel faktörler, } \\
& \text { c.Bankacılıkta yapılan hatalar. }
\end{aligned}
$$

\section{II.1.1. Firmaya Ait Nedenler}

Kredinin sorunlu hale dönüşmesinde firmanın özellikleri açısından etkili olabilecek faktörler şöyle siralanabilir:

Yönetim: İşletmelerin başarısızlıklarında kötü yönetimin payı oldukça büyüktür. Kötü yönetim bilgi, uzmanlık ve tecrübe eksikliğinden ortaya çıkabileceği gibi sorumsuzluktan ve kötü niyetten de kaynaklanabilir. Yetersiz planlama çoğu kez yönetsel sorunlara yol açmaktadır. Kısa ve uzun vadeli planlardan yoksun bir firma elindeki firsatları değerlendirme ve çevresel koşullardaki değişimlere uyum gösterme özelliğini yitirecektir. Amaçlar ve gideceği yönü belirlenmemiş bir firma dış faktörlerin etkisiyle önceden öngörülmeyen sonuçlara doğru daha kolay sürüklenebilir. Yöneticilerin ileriyi görme ve planlama yeteneği ne kadar fazla ise başarı olasılığı da o kadar yüksek olmaktadır.

Üretilen Mal: Bir firmanın faaliyetlerini karlı bir şekilde sürdürülebilmesi, ürettiği malın piyasadaki üstünlüğünü ve kalitesini istikrarlı olarak koruyabilmesine yakından bağlıdır. Hammadde veya enerji teminindeki zorluklar, kaliteli iş gücünün bulunmaması ürünün maliyetini ve hatta üretim hacmini olumsuz olarak etkileyebilir. Öte yandan tüketim tercihlerinin değişimler veya yeni teknolojik gelişmeler ürünün piyasadaki durumunu değiştirebilir. İşletmenin ürettiği malı etkileyen bu faktörlerden herhangi bir tanesi firmanın karlılığını ve borç ödeme gücünü olumsuz olarak etkileyebilir.

Pazarlama Koşulları: Sorunlu kredilerin nedenleri araştırılırken firmanın pazarlama faaliyetleri yakından incelenmelidir. Kredi borçlusunun iyi tanımlanmış bir pazarlama politikası ve bu politikasını uygulayabileceği etkin araçları olmalıdır. Dağıtım kanallarının doğru olarak seçimi, fiyat politikasının saptanması, reklam kampanyalarının oluşturulması pazarlama faaliyetlerinin temelini teşkil eder. Firma etkin bir pazarlama planı oluşturamaz ve piyasadaki konumunu ve rolünü iyi belirlemezse, bu tutum satışlarının karlılığının düşerek sorunlu kredileri dönüşmesine neden olabilir.

Kontrol Sistemleri: Bir firma doğru ürünü doğru pazarda etkin bir pazarlama stratejisi ile pazarlayabilir ancak faaliyetleri gerektiği gibi kontrol edemiyorsa başarısızlık kaçınılmaz olabilir. Bir işin sağlıklı 
yönetilebilmesi için alacakları, stokları genel üretim giderlerini kontrol edecek sistemleri, ürün kalitesini, varlıkların, giderlerini kontrol altında tutacak, suiistimalini önleyecek mekanizmaları, bütçeleri, projeksiyonları, planları olmalıdır. Kontrolsüz bir firmada herhangi bir sorun teşhis edilmeden büyüyebilir ve çözümü imkansız hale gelebilir.

\section{II.1.2. Çevresel koşullar}

Çevresel koşullar firmanın hayatiyetini sürdürebilmesi için daha önceden öngörülerde bulunarak planlaması gerektiği ekonomik faktörler, hükümet kararları veya teknolojik değişimler gibi firma dışından kaynaklanan koşullardır.

Teknolojik Çevre: Bir firmanın değişen teknolojik koşulları belirleyip bu değişmelere zamanla uyum sağlayabilmesi finansal istikrarı ve hayatiyeti açısından oldukça önemlidir. Daha gelişmiş yenim ürünlerin piyasaya sunulması ve üretim teknolojisindeki iyileşmeler bir firmanın malına olan talebi ve piyasadaki rekabet gücünü hızla etkileyebilen gelişmelerdir.

Ekonomik Çevre: Bu işi başarılı bir şekilde yönetebilmek için, içinde bulunulan ekonomik koşulların mutlaka iyi değerlendirilmesi gerekir. Ekonomik dalgalanmalar vergiler, faiz oranları, satın alma gücündeki değişmelerin firmanın başarısını ve dolayısıyla borç ödeme gücünü önemli ölçüde etkileyecektir. İşkolunun niteliği işletmenin ekonomik dalgalanmalara ne ölçüde duyarlı olacağını belirler. Bazı sektörler ekonomik değişkenlerle ve genel trendlerle aynı yönde etkilenirken bazı sektörlerin etkilenmeleri ters yönde olabilir.

Doğal Çevre: Bir çok firma hammadde temini ve enerji ihtiyacı nedeniyle doğal kaynaklara bağımlıdır. Bu kaynakların temini ve maliyeti arz ve talep koşullarına, politik ve çevresel nedenlere bağlı olarak değişebilir. Örneğin petrol fiyatlarındaki değişim geniş çapta bütün iş hayatını etkisi altına alabilmektedir. Öte yandan yangın, sel, kuraklık, don ve diğer doğal felaketlerde firmanın hammaddesini temin etmesini ve faaliyetlerini sürdürmesini etkileyebilir.

Politik Çevre: Bir çok firma açısından hükümetlerin aldığı kararlar ve yasal düzenlemeler firma yönetimini ve başarısını önemli ölçüde etkilemektedir. Asgari ücretlerde yapılan değişiklikler, vergiler ithalat ve ihracat koşullarına getirilen kısıtlamalar, verilen teşvikler sermaye piyasasını işleyişine ve bu piyasadan fon temin etmeye yönelik kısıtlamalar veya imkanlar, fiyat kontrolleri firmalarının başarılarını önemli ölçüde etkileyebilmektedir [2].

\section{II.1.3. Kredilendirme Sürecinde Yapılan Bankacılık Hataları}

Bazı durumlarda kredilerin sorunlu hale dönüşmesinde kredi tahsis edenlerinde payı bulunabilir.

Borçlunun Hakkında Yapılan İstihbaratın Yeterli Olmaması: Borçlunun yönetim kapasitesinin yeterince araştırılmaması olumsuz finansal bilgilerin yönetiminin başarısızlığı olarak değerlendirilmesinden ziyade dış faktörlere (rekabet, kötü ekonomik koşullar gibi) bağlanması tahsis edilmemesi gereken bir kredinin bankanın portföyüne dahil edilmesine neden olabilir.

Finansal Tabloların Yetersiz Analizi: Finansal tabloların zaman baskısı nedeniyle uzman kişiler tarafından değil de tecrübesiz analistler tarafindan değerlendirmesi sorunlu kredilere neden olabilir.

Kredinin Amacının ve Geri Ödeme Kaynağının Yetersiz Analizi: Kredinin amacının ve geri ödeme kaynaklarının yeterli derecede analiz edilmemesi çoğu zaman kredinin sorunlu hale dönüşmesine neden olmaktadır. Krediyi tahsis eden yönetici firmanın faaliyetlerini iyi anlayamazsa firmanın nakit akışını, dolayısıyla finansman ihtiyaçlanını doğru olarak saptamayacak ve sağlayacağı finansmanı bu ihtiyaçlar doğrultusunda yapılandırmayacaktır. Kredi tahsisinin ve geri ödenmesinin doğru olarak zamanlanmaması, vadelerin firmanın nakit akışı ile uyumsuz olmasına neden olacaktır. Bir çok sorunlu kredi yöneticisinin işi, sektörü ve ekonomik çevreyi iyi etüt etmesiyle önlenebilir. Faaliyet döngüsüne göre düzenlenen geri ödeme dönemleri kredi borçlusunun yükümlülüğünü daha rahat yerine getirmesini sağlayacaktır.

Yetersiz Teminat: Bilindiği gibi tahsis edilen kredilere karşı borçludan alınan teminatlar bankaya olası zararlara karşı korur. Alınan teminat, pazar değeri ve piyasada satılabilirliği açısından yeterli olarak değerlendirilmişse olası bir zararla karşılanabilir. Teminatın yeterli özellikleri olsa bile bankanın bu teminat üzerinde yasal hak iddia edilmesi için belgelemenin doğru bir şekilde yapılması gereklidir.

Yetersiz İzleme: Firmanın ve kredinin kalitesinin ne yönde değiştiğinden haberdar olmak için etkin bir izleme şarttır. Firmadan dönemsel olarak finansal dönemsel olarak finansal verilerin istenmesi, firmaya dönemler itibariyle ziyaretler yapılması, değişen ekonomik koşulların borçlu üzerindeki etkilerinin izlenmesi kredi kalitesindeki değişimi ortaya koyan izleme teknikleridir. Özlemenin yetersiz olması halinde sorunlar zamanında far edilmeyecek ve sorun su yüzüne çıkınca bankayı koruyacak önlemlerin alınmasında gecikilmiş olarak zarar ortaya çıkabilecektir. 
Kredi Fonksiyonunun Yönetiminde Yetersizlikler: Kredi fonksiyonunun iyi yönlendirilmemesi, kredi politikasının kredi fonksiyonuna yeterli derecede yön verecek şekilde belirlenmemesi, kredi kalitesinin düşmesi pahasına kar ve büyüme hedefinin gözetilmesi, iyi eğitilmemiş kişilerin bu departmanda çalıştırılması, sorunlu kredi miktarını arttıracaktır.

Hızl Büyümenin İzlenmemesi ve Kontrol Altına Alınamaması: Sorunlu kredilerin nedenleri arasında en sik rastlananlardan bir tanesi de hizlı büyümedir. Yatırımların ve satışların hızla artması firma yöneticilerinin kontrolü kaybetmelerine ve firmanın sağlıklı büyümesini finanse edecek iç ve dış kaynakların zorlanmasına neden olabilir. Kontrol edilmeyen büyüme sonunda firmayı önemli bir akit darboğazına sokabilir ve banka firmayı hayatta tutabilmek ve önceki borçların tahsil edebilmek amacıyla yeni krediler açmaktan başka çare bulamayabilir. Böyle bir sonuç ise, kredi borçlusunun normal koşullarda borcunu geri ödeme kapasitesini yitirdiğini ve bankanın eline son derece sınırlı seçenekle baş başa kaldığını göstermektedir.

Sorunun Teşhis Edildiği Anda Önlem Almada Gecikme: Kredilerde en çok yapılan hatalardan bir tanesi de sorunun teşhis edildiği anda hemen harekete geçmemektedir. Bu yaklaşım çoğu zaman sorunu daha da büyütür ve zarar olasılığı arttırır. Bankadaki sorumlu yönetici müşteriyi sıkıştırmaktan çekinirse veya şahsi korkuları nedeniyle problemi kabul etmekten kaçınırsa durum kontrol altına alınmayacak derecede kötüleşebilir [3].

\section{II.2. Sorunlu Kredilerin Oluşmasına Karşı Alınacak Önlemler}

Kredilerin sorunlu hale düşmesini engelleyecek çeşitli önlemler almak mümkündür. Etkin izleme programları uygulayarak, tehlike işaretlerini önceden saptayarak ve bozulmaya yüz tutan banka müşteri ilişkisini erken bir safhada teşhis ederek kredi riskini minimize etme çabası başarıyla sonuçlandırılabilir [2].

\section{II.2.1. İzleme Yöntemleri}

Yetersiz ve etkinliği olmayan izleme yöntemleri sorunlu kredilerin en önemli nedenleri arasıda yer almaktadır. Amaca uygun şekilde iyi yönlendirilmiş izleme programları sayesinde gelişmekte olan sorunlar erkenden teşhis edilebilmektedir. Her izleme programının mutlaka aşağıdaki aşamaları kapsaması gerekir [4].

Kredi müşterisinden mutlaka belirli aralıklarla finansal tablolar istenmeli ve bu tablolar analize tabi tutulmalıdir.
- Düzenli bir şekilde müşterinin bürosu ve fabrikaları ziyaret edilmeli ve müşteri ile ilişki sürdürülmelidir.

- Düzenli bir şekilde sektör raporları, ticaret ve sanayi odası raporları incelenmelidir.

- Kredi müşterisinin rakipleri, mal satanları ve müşterileri ile diğer finansal kurumlar hakkında istihbaratlardan sürekli haberdar olunmalıdır.

\section{II.2.2. Tehlikeli İşaretlerin Zamanında Farkuna Varılması}

Krediler genellikle hiçbir uyarı işareti vermeden birden bire problemli hale gelmektedir. Hemen her olayda mutlaka bazı uyarı sinyalleri gözlemlenebilir. Bu uyarıcı sinyaller vaktinde izlenip doğru yorumlanırsa yaklaşan tehlikeye karşı önlem alınabilir ve çözüm bulmak daha kolaylaşabilir.

Erken uyarı sinyalleri beş grupta toplanabilir [4]:

- Finansal: Bu sinyaller en kolay finansal tablolardan alınabilir.

- Yönetim: Firma yöneticileriyle yapılan toplantılardan bu sinyalleri teşhis etmek mümkün olabilir

- Faaliyetler: Firma faaliyetlerindeki bozulmaları teşhis edebilmenin en iyi yolu firma ziyaretlerinde bulunmaktır.

- Bankanın İzlenmesi: Kredi koşullarına uyumun, teminatın ve kredinin sıkı bir şekilde takibi ve izlenmesi tehlike sinyallerinin önceden alınması hayati önem taşır.

- Diğer kaynaklar.

\section{II.2.2.1. Finansal Erken Uyarı Sinyalleri}

Finansal erken uyarı sinyalleri firmanın bilanço, gelir tablosu ve bunların dipnotlarından elde edilmektedir;

(i) Bilançodan elde edilebilecek sinyaller;

1-Bilançoların zamanında alınması

2-Bilanço (Aktif toplamın küçülmesi)

3-Likidite yapısının değişmesi

- Toplam aktifler içinde yüzdesel olarak dönen varlıkların düşmesi

- Dönen varlıklar bileşiminde önemli değişiklikler 
- Alacaklarda tutar ve yüzde olarak artış

- Stoklarda önemli artışlar, bileşiminde önemli değişimler

- Ortaklardan ve grup kuruluşlarından olan alacaklarda artış

- Likiditenin ve net işletme sermayesinin azalması

4-Duran varlıklarda hızla değișen yoğunlașma ve artışlar önemli azalışlar

5-Devam eden yatırımlar (montajı, zamanı, finansman kaynağı)

6-Finansal yapının değişmesi artışlar

- Borçlar toplamında tutar ve yüzde olarak önemli

- Kısa süreli borçlarda önemli artışlar ve bileşimin finansal borç lehine değişmesi

- Ticari borçlarda önemli artışlar

- Borca göre yetersiz özvarlık

- Satışlara göre yüksek borçlanma

- Satışlara göre yüksek banka ve diğer finansal borçlar

- Özkaynak bileşiminde değişmeler.

7-Alacakların yaşlandırılması ve değerlendirilmesi düşmesi)

- Alacak yaşının uzaması (Alacak devir hızının

- Satış protokolünün değişmesi (peşin, vadeli oranı, vade farkı)

- Satışların belirli müşterilere yoğunlaşması oluşması

- Önemli ölçüde vadesi geçmiş alacakların

- Grup şirketlerinden alacakların artması

(ii)Gelir tablosundan elde edilebilecek sinyaller:

1-Azalan reel olmayan satışlar

2-Çok hızlı büyüyen satışlar
3-Brüt ve net satışlar arasında önemli farklılığın bulunması (iade, iskonto) daralmas

4-Maliyetlerin yükselmesi ve kar marjlarının

5-Faaliyet giderlerinin satışlardan fazla artması ve satışlardaki payının büyümesi

6-Finansman giderlerinin satışlardan fazla artması ve satışlardaki payının büyümesi

7-Artan satışlara karşın azalan karlar

8-Dönem karının, daha çok diğer gelir ve olağanüstü gelirlerden oluşması (Esas faaliyetlerden fon yaratılamaması)

9-Faaliyet zararları

10-Dönem karını etkileyen değerleme yöntemleri (alacak ve borç senet reeskontları, stok değerleme, döviz kur farkları, amortismanlar, aktif değer düşüş karşılıkları, aktifleştirilen finansman giderleri vs.)

(iii) Bilanço ve Gelir Tablosu dipnotlarından elde edilebilecek sinyaller:

(iv)Denetim raporunun zamanında yayımlanmaması ve olumsuz görüş bildirilmesi

\section{II.2.2.2. Yönetim Konularında Erken Uyarı Sinyalleri}

(i) Yönetim ve planlama süreçlerinden elde edilebilecek sinyaller

1-Yönetim ve sahip değișikliği

2-Kilit adamların hastalığı veya ölmesi

3-Yeni ve ilgilisiz ortaklar

4-Yükümlülüklerin ve verilen sözlerin zamanında yerine getirilmemesi

5-Anahtar yönetici ve ortaklarda içki, kumar ve gece hayatı gibi davranışsal boyutta görülen değişiklikler düşkünlük

6-Așırı para harcama eğilimi ve gösterișe

7-Borca dayalı aşırı ve hızlı büyüyerek firma kaynaklarının zorlanması

8-Yeni işlere, yeni coğrafi bölgelere ve yeni ürünlere yeterince inceleme yapmadan yatırımda bulunmak 
(ii) Kontrol sürecinden elde edilebilecek sinyaller

1-Zayif mali kontrol (Finansal veri ve faaliyetlere hakimiyet zayıflı̆ı)

2-Iyi bir iç kontrol sisteminin olmayışı

(iii) İletişim sürecinden elde edilebilecek sinyaller

1-Kurum içi birimlerde iletişim eksikliği

2-Banka iliş̧ilerinde davranış değişikliği (verilen sözleri yerine getirememe işbirliğinden kaçınma) sinyaller

(iv) İnsan kaynakları sürecinden elde edilebilecek

1-Bilgili ve yetişmiş personel eksikliği güçlüğü)

2-İşçi problemlerinin oluşması (grev, eleman temin

(v) Faaliyet gösterilen Pazar ile ilgili erken uyarı sinyalleri gecikmek

1-Değișen Pazar koșullarına uyum sağlamada

2-En büyük müşteri ve müşterilerin kaybedilmesi

3-Firmanın Pazar durumunda olumsuz gelişmeler gözlenmesi

(vi) Faaliyetler ile ilgili diğer erken uyarı sinyalleri

1-Gerçekçi olmayan fiyatlama

2-İhalelerin çok iskonto ile alınması

3-Bozulan stoklar olma

4-Satılamayan veya gereğinden fazla stoka sahip

5-Spekülatif amaçlı stok bulundurma

6-Eski teknoloji kullanımı

7-Yetersiz makine parkı

\section{II.2.2.3. Faaliyetlerdeki Erken Sinyalleri} değişimler

1-Firmanın iş konusunun özelliklerindeki

2-Kötü finansal sonuçlar ve kontroller
3-Üretim kapasitesinin ve firmanın yetersiz olması

4-İşgücünün iyi kullanılmaması

5-Güvenirliği yüksek olan bir veya daha fazla önemli müşterinin kaybedilmesi

6-Önemli üretim kanallarının, dağıtım haklarının veya hammadde kaynaklarının kaybedilmesi veya elden çıkarılması

7-Üretim kapasitesini zorlayacak büyüklükte sipariş alınması

8-Normal satın alma uygulamalarının dışında spekülatif hammadde alımları

9-Fabrika, teçhizat ve ekipmanın bakımsızlığ

10-Eskiyen teçhizatı yenilenmemesi

11-Yüksek miktarlarda stok birikimi, bozuk stoklar

12-İşgörenlerin devir hızlarının ve devamsızlık oranlarının yüksek olması

\section{II.2.2.4. Banka İşlemlerinde Erken Uyarı Sinyalleri}

1-Müşterinin bankadaki mevduatında düşmeler

2-Teminata alınan senetlerin temdit edilmesi

3-Sabit varlık alımına veya işletmeye sermaye ihtiyacına yönelik yanlış veya kötü planlama

4-Büyük ölçüde kısa vadeli kredi kullanımı

5-Kredi taleplerinin miktarının ve sıklığının büyük sıçrama yapması

6-Tek bir geri ödeme kaynağının dışında başka gerçekçi bir kaynağın belirlenemediği krediler

7-İşletme sermayesi amaçlı krediler

8-Kredi müşterisine mal temin edilen grupların bankadan, firmaya açacakları yeni krediler ve özel vadeler nedeniyle istihbarat talep etmeleri varlığı

9-Protestolu senetlerin ve karşılıksız çeklerin

\section{II.2.2.5. Diğer Kaynaklardan Gelen Erken Uyarı Sinyalleri}

(i) Resmi makamlarda gelen erken uyarı sinyalleri 

ihtiyati haciz)

1-Firma hakkın ön tedbir kararlar1 (İhtiyati tedbir,

2-Firma hakkında alınan cebri kararlar (Haciz, Ifflas, Konkordato, İhale Yasağı, Çalışma konusu ile ilgili yetki belgesi iptali, Hakkında açılan kavuşturma, diğer bankalar tarafından takibe alınma)

(ii) Üçüncü şahıslardan gelen sinyaller

Bankalardan, alacaklılardan, piyasadan, basından gelen olumsuz istihbarat ve haberler

\section{II.2.3. Bozulan Banka Müşsteki İlişkileri}

Bir çok durumda banka bu sinyalleri önemsemez veya tamamen ihmal eder. O zaman daha vahim bir sinyal bankaya problemin varlığını kabul ettirir. Problemin varlığı, müșterinin banka ile ilişkilerinin bozulması borç ödemelerinin gecikmesi, limit aşımı, karşılıksız çek, kredi sözleşmesinin koşularının ihmal edilmesi ile kendini gösterir. Çoğu kez bir üçüncü tarafta bankayı problem hakkında uyarır. Bu uyarılara örnek olarak şu durumları verebilir:

- Çalışanların sigorta primlerinin ödenmemesi halinde sigortadan gelebilecek uyarı

- Müşteri hakkında mahkemede açılan davalar

- Mal temin edenlere geciken ödemeler veya müşterinin vade uzaması talebi karşısında sevkıyatın yapilmasi

\section{- Çalıșanlara yapılacak ödemelerde gecikmeler}

Bankanın müşteriden finansal durumu hakkında zamanında bilgi alamaması, bankanın sorunlu bir krediyle karşı karşıya kalacağının bir göstergesidir. Kredi yönetimi müșteriden mutlaka düzenli aralıklarla bilgi istemeli, müşterinin finansal bilgilerini bankayla paylaşmaktan kaçınması veya bu bilgileri hazırlanmamış olması halinde bu ciddi bir uyarı olarak değerlendirmelidir.

\section{II.3. Sorunlu Kredilerde Çözüm Yolları}

Bir kredinin sorunlu hale dönüștüğü belirlendiği andan itibaren hemen harekete geçilmelidir. Alınacak ödemelerde ve izlenecek yolda bankacı ilk önceliği geri ödemenin güvence altına alınmasına ve durumunun korunmasına vermelidir. Bu temel amaca bağlı olarak bankanın çıkarlarının korunmasının en iyi yolu müşterinin finansal durumunun sağlıklı hale getirilmesini sağlamak olabilir. Bu başarıldığı takdirde bankanın borcunun geri ödemesi güvence altına alınması ve müşterinin banka ile arasındaki iyi ilişkiler güçlendirilmiş olur. Eğer bir kredinin zarara dönüşmesi olasılığı çok fazla artmışsa bankanın karşısında üç seçenek mevcuttur. etmek

- Müşteri ile ilişkilerin sürdürülmesine devam

- Teminatı paraya çevirmek

- Hiçbir harekette bulunmamak

\section{II.3.1. Sorunlu Kredilerin Çözümlenmesinde Yaplacak Ön Analizler}

Bankanın çıkarlarını koruyacak en doğru kararın alınabilmesi için herhangi bir harekete geçmeden önce bankacı çeşitli unsurları değerlendirmelidir.

$\mathrm{Bu}$ unsurlar müşteri, müşterinin cari hesapları, kredi dosyası ve alınan teminatlardır. Bu aşamada bilgi alınabilecek en iyi kaynak avukatlar, muhasebeciler ve diğer kredi veren gruplardır.

Müşteri: $\mathrm{Bu}$ aşamada bankac1 müşterinin sorununu çözebilecek yeteneğe sahip olmadığına ve ne derece dürüst ve güvenilir olduğuna karar verebilmelidir. Sorunlu bir kredinin çözümü için mutlaka var olması gereken özellik karşılıklı güvendir. Eğer işin içinde ahlak dışı yaklaşımlar mevcutsa bankacı için tek seçenek teminatların nakite çevrilmesi ve gerekli hukuki önlemlerin alınmasıdır.

Müşterinin Çelkli Mevduat Hesabı: Sorun ortaya çıktığı anda müşterinin çek hesabını gözden geçirmek ve hesaptan kimlerin para çekip hangi borçluya yapıldı ğını belirlemek gerekir. Ayrıca bu hesap kontrolü altında büyük çekilişler önlenmelidir.

Kredi Dosyası: Kredi hakkında gerekli bilgilerin yer aldığı kredi dosyası ortaya çıkan sorunlara 1 şı tutabilecek en iyi kaynaklardan biridir. Kredi dosyasındaki verilerden firmanın cari finansal durumu yeniden analiz edilmelidir. Eğer dosyadaki bilgiler yetersiz veya eksikse böyle bir durumu kötü belgeleme olarak da değerlemek mümkündür.

Teminat: Bir teminat ancak gerekli hukuki koşullar takip edilip bankanın mülkiyetine geçirilmişse ve satıldığı zaman borcu ödeyebilecek kaynağı yaratıyorsa bir kıymet ifade eder. Ancak çoğu kez bir sorun ortaya çıkması halinde, teminatın alındığı zaman yapılması gereken hukuki işlemlerin ve temin edilmesi gereken belgelerin dosyada olmadiğg görülür.

Avukatlar ve Muhasebeciler: Zorunlu bir kredi durumu ortaya çıktığı zaman başvurulacak iki önemli grup bankanın avukatları ve müşterinin muhasebecileridir. Avukatlar sorunun çözülmesinde gerekli hareket planının hazırlanmasında bankaya yardımcı olurlar ve bankanın 
takip edeceği hukuki yolları önererek, bu hukuki çareleri kullanilmasını engelleyecek unsurlara çözüm ararlar.

Müşteriye Diğer Borç Veren Kişi veya Kuruluşlar: Bankanın diğer kreditörlerin kimliğini ve bu kreditörlere zamanında ödeme yapılıp yapılmadığını izlemesi gerekir. Çoğu kez borçlu taraf, kendisi ile en yakın ilişkiyi geliştiren borç verene karşı kendisini daha sorumlu hissetmektedir. Eğer banka müşteri ile sağlam bir ilişki kurabilmişse sorunu diğer kreditörlere kaydırabilir, müşteriye mal temin edenlere ödemenin yapılmasında yardımcı olacak müşterinin faaliyetlerini sürdürmesini sağlar.

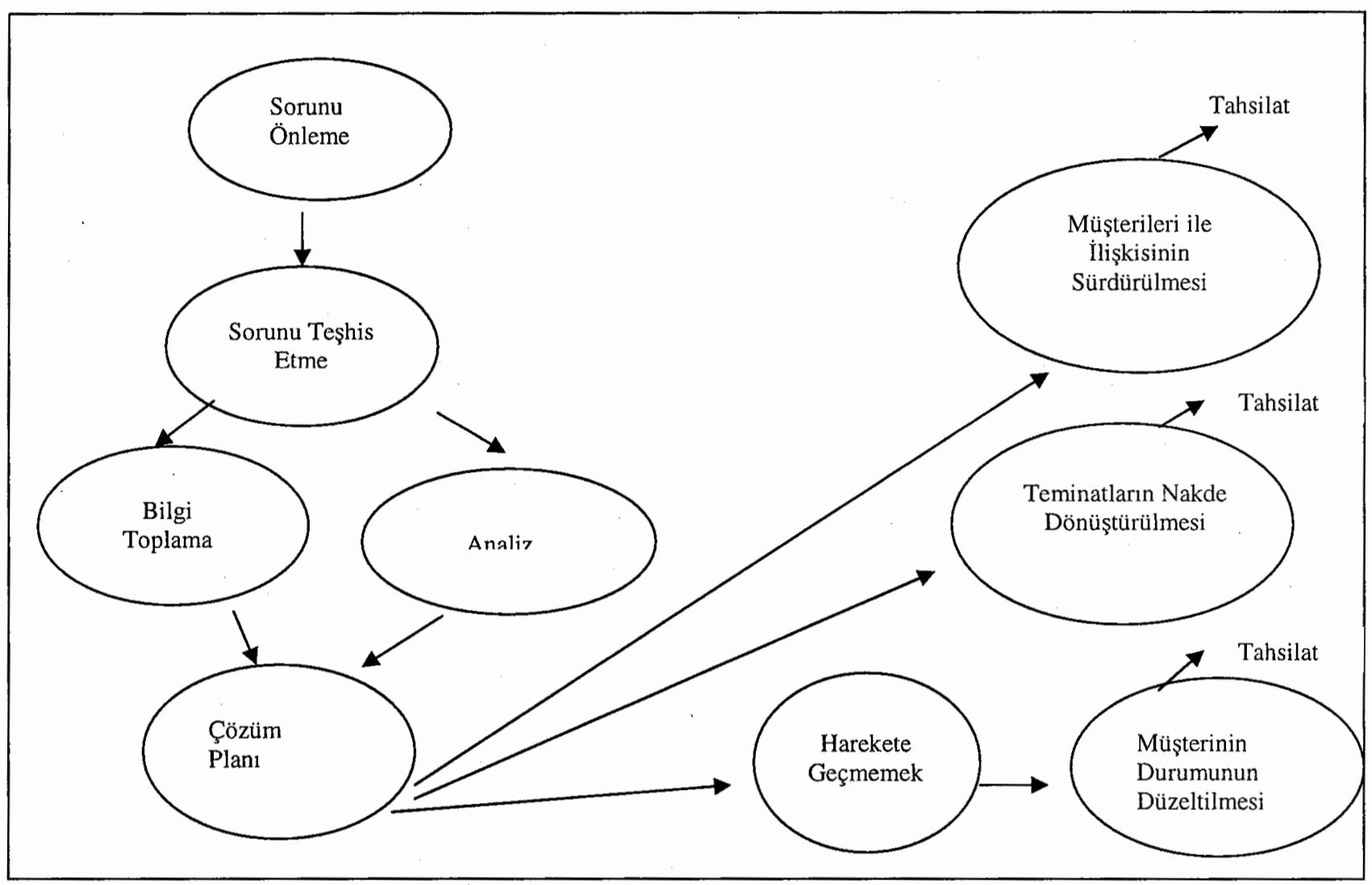

Şekil.1: Sorunlu Kredide Çözüm Süreci

\section{II.3.2. Sorunlu Krediyi Çözecek Kişinin Seçimi}

Sorunlu bir kredinin farkına varılır varılmaz bu kredi ile kimin ilgilenmesi gerektiğine karar verilmelidir. Burada genellikle iki yaklaşım mevcuttur. Birçok banka sorunlu bir kredinin çözümünde uzmanlaşmış, tahsilat ve hukuki süreçlerde deneyimli kişileri tercih etmektedir. Bu şekilde uzmanlaşmış bir kişi soruna ve çözümüne daha fazla zaman ayırabilmekte, kredi tahsis eden yönetici ise yeni ve daha karlı işlere yönelebilmektedir. Öte yandan kredi ile ilgilenen yöneticinin değiştirilmesi bankanın müşteriye sorunu ciddiye aldığı mesajı vermektedir. Ayrıca yeni yöneticinin kredi ile hiçbir duygusal bağı olmaması daha fazla objektif olma şansı vermektedir.

Sorunlu kredinin kimin tarafından çözüleceğine ilişkin ikinci yaklaşım ise krediyi tahsis eden kişinin sorunun çözümü ile görevlendirilmesidir. Buradaki yaklaşım kredi tahsis eden yöneticinin kendi hatalarından sorumlu tutulmasıdır. Ayrıca krediyi tahsis eden kişinin firmayı ve sektörün koşullarını daha iyi bilmesi daha çabuk karar almada yardımeı olabilir. Ancak sorunun çözümü için kim görevlendirilirse görevlendirilsin banka içinde daha deneyimli kişilerin birikimlerinden yararlanmak gerekir. Sorun ortaya çıtıktan sonra müşteri ile bir araya gelerek bir toplantı düzenlenmeli ve bu toplantıda şunlar görüşülmelidir;

\section{- Sorun etraflica tartışılmalı.}

- Borçlu ve banka sorunun çözümü için seçenekler belirlemelidir.

- Her iki tarafın kabul edeceği ve etmeyeceği çözümler ortaya çıkarılmalıdır.

\section{II.3.3. Sorunlu Kredilerin Çözümü İçin Bankanın Önündeki Alternatifler}

Banka yukarıda belirtilen konularda ön analizlerini yapıp durumu açıkça ortaya koyduktan sonra ne şekilde 
hareket edeceğine karar verir. Sorunlu kredilerin çözümü için tek bir formül ya da yöntemin olamayacağı doğaldır. Her sorunlu kredide çözüm durumunun ve koşullarının kendi özelliklerine uygun olarak bankanın riskini en düşük düzeyde tutacak şekilde geliştirilmelidir. Sorunlu bir kredinin çözümüne yönelik bankanın önünde üç seçenek mevcuttur.

\section{II.3.3.1. Müşteri İle İlişkilere Devam Etmek}

Eğer müşteri ile ilişkilerin sürdürülmesine karar verilmişse banka aşağıdaki hareket planını uygulamaya koymalıdir.

1- Sorunlu Kredi Durumunun İyileştirilmesine Yönelik Bir Planın Geliştirilmesi: Bankanın müşteri ile ilişkilerini devam ettirmesi için işletmenin varlığını sürdürüyor olması yönetimin güçlü ve işin başında olması, yönetimce hazırlanmış, sorunları düzeltecek önlemleri içeren bir planın mutlaka bulunması gerekir. Banka bütün bunların yanında tahsis edilecek yeni kredilerle firmanın sorunlarını çözeceğine, ek avansların geri ödeneceğine ve ilk tahsis edilen kredinin daha büyük bir kısminın tahsil edilebileceğine inanması gerekir. Bankanın olumsuz koşullarda dahi firmanın kar ve nakit akımı yaratarak borcu kabul edilebilir bir sürede geri ödeyebileceğine dair inancı olabilmesi için firmanın durumunun bu koşulları yerine getirebilir özellikte olması gerekir. Bankanın hazırlanan planın gerçekçiliğini saptayabilmesi için firmanın tüm borçlarının (nakdi, gayrinakdi, ticari, kira ödemeleri) tam olarak dökümü bilinmelidir.

2- Nakit Bütçesinin Hazırlanması: Nakit bütçesinin yardımıla firmanın bu dönemde ihtiyaç duyduğu fon miktarı belirlenebilir. Bu fonlar işletmeyeyi tekrar karlı bir faaliyet düzeyine getirebilmek üzere stok veya ticari alacak gibi işletme sermayesi olarak kullanılabileceği gibi zararın finansmanında veya üretim düzeyini arttıracak sabit varlık yatırımlarında kullanılabilir.

3- Finansal Tabloların Hazırlanmasi: Banka en az on iki aylik bir dönemi kapsayan proforma bilanço ve gelir tablosu hazırlamalı ve bu tabloların yardımıla en kötü koşullar altında ve en karamsar nakit ihtiyacı tahminleriyle geri ödeme olanaklarını ön görebilmelidir. Ancak öngörülen geri ödeme vadeleri gerçekçi olmalıdır. Tabloların hazırlanmasında amaç ihtiyaç duyulan fon miktarının belirlenmesi, bankanın en erken borcunu ne zaman tahsil edebileceğini görmesi ve kredinin geri ödenebilirliğini değerlendirmesidir.

4- Fon Kaynaklarının Saptanması: İhtiyaç duyulan fon miktarının belirlenmesinden sonra alternatif fon kaynaklarının araştırılması gerekir. İlk düşünülmesi gereken kaynak öz varlığın arttırılması olmalıdır. Üretim için ihtiyaç duyulmayan sabit varlıkların veya yan kuruluşların satılışı da ek kaynak yaratabilir. Çoğu żaman önemsenmeyen bir fon kaynağ ise işletmenin hacminin küçülmesini sağlayabilir. $\mathrm{Bu}$ da cari varlıkların azaltılması veya daha etkin kullanımı için gerçekleşebilir. Stok dönme çabukluğunun arttırılması veya daha etkin kullanımı için gerçekleşebilir. Stok dönme çabukluğunun arttırılması ve alacak tahsil süresinin kısaltılması işletmenin son derece ihtiyaç duyduğu nakit fonlanı serbest kalmasına neden olur. Satış hacminin azaltılması ve stoklara ve ticari alacaklara yapılan yatırımı azaltacağından bağlı fonları serbestleştirecek ancak karlılığı tehlikeye düşürebilecektir.

5- Müşteri İle İyi İlişkilerin Korunması: Sorunlu krediye yol açan yönetim hakkında bankanın kararı ne olursa olsun kredi yöneticisi borçlu ile iyi ilişkilerini sürdürmeli sorunu kişiselleştirerek olaya veya duygusal bazda yaklaşmamalıdır. Bankacının gösterebileceği en iyi tutum borçlu ile dayanışma içinde sorunun çözümü için çalışmak, bu arada yönetimin kapasitesini ve kısıtlarının gözlemlemek olmalıdır.

6- Ek Fon Tahsis Edilmesi: Eğer müsteriye yeni fonlar tahsis edilecekse mutlaka imkanların elverdiği ölçüde yeni teminatlar alınmalıdır. Bu teminatlar ikinci derece de olsa dahi bankanın durumunu güçlendirmek üzere alınmalıdır. Bunun yanında var olan sözleşmesi daha da sıkıştırılmalıdır.

7- İzleme: Müşteri ile ilişkilerin devam ettirilmesi kararı alındıktan ve bir hareket planı oluşturulduktan sonra durumun sürekli takibi analizi şarttır. Elde edilen sonuçlarla öngörülen finansal tablolar karıştırılmamalı ticari çekler izlenmeli ve firma ziyaretleri sıkça yapmalıdır. Bu arada borçlunun tutumu ve bankaya karşı borcunu ödemede ne derece istekli olduğu sürekli olarak izlenmelidir. Eğer borçlu hazırlanan plandan ayrılarak önemli ölçüde yardımlaşmadan kaçınıyorsa müşteri ile ilişkilerin sürdürülmesi kararı yeniden gözden geçirilmelidir.

$\mathrm{Bu}$ seçeneğin yarattığı bazı sorunlar aşağıda özetlenmiştir:

1- Borçlunun Üzerindeki Baskı Azalır: Borçluya yeni kredinin tahsis edilmesi geçici olarak da olsa borçlu üzerindeki baskısını azaltacaktır. $\mathrm{Bu}$ da borçlunun bankaya borcunu geri ödeme gayretini azaltmasına ve fonları kendisine daha fazla baskı yapan borç verenlere kaydırmasina neden olabilir.

2- Diğer Borç verenler Üzerinde Olumsuz Etki Yapabilir: Yeni bir kredi tahsisinde ek teminatların alınması özellikle stoklar üzerinde rehinlerin konması mal gönderenlerin sevkıyatı durdurmalarına veya kredili satış yapmamalarına neden olabilir. 
3- Yeni Kredi Tahsisini Zorunlu Klabilir: Bankanın ek fon sağlamaya devam etmesi sonucunda banka o kadar büyük bir risk altına girebilir ki finansal desteği kestiği anda kendisi içinde durum vahim olabilir. Yukarıda açıklandığı gibi sorunlu kredilerin çözümünde müşteri ile ilişkilerin sürdürülmesi seçeneği oldukça büyük riskler taşımaktadır ve bütün bu faktörler böyle bir karar alınmadan hesaba katılmalıdır. Ancak borçlunun da katkısı ile bankanın desteği birleştirilerek müşterinin yenide sağlıklı bir yapıya kavuşturulması sorunun çözümünde en az masraflı ve en etkin yol olarak belirgin yerini korumaktadır.

\section{II.3.3.2. Teminatın Paraya Çevrilmesi}

Sorunlu kredilerin çözümünde ikinci seçenek daha önce alınmış teminatların paraya çevrilmesi için harekete geçmektedir. $\mathrm{Bu}$ yöntem uzun boylu araştırma ve analiz gerektirmeyeceği için süratle uygulamaya konabilir ve bankaya zaman kazandırır. Ayrıca bankanın ek kredi tahsis ederek riskini daha da arttırmaz. Ancak süratli ve sorunsuz bir tasfiye işleminin gerçekleşmesi için borçlunun da yardımcı olması şartıı. Eğer borçlu bankanın tasfiye işlemlerini engellemeye yönelirse bu işe ayrılan zaman ve para (ödenmeyen faizler, hukuki giderler, teminatın azalan değeri) o kadar büyük boyutlara varabilir ki bu işten elde edilecek fayda zarara dönüşebilir.

Teminatın paraya çevrilmesi en kolay olarak gözükse bile her zaman bankanın zararını en alt düzeyde tutacak en etkin çözüm olmamaktadır. Çoğu kez teminatın nakde çevrilmesiyle elde edilecek fonların ne kadar olacağı önceden öngörülmektedir. Özellikle teminat stoklardan ticari alacaklardan teçhizat ve gayrimenkulden oluşmaktaysa bunların tasfiyesi için geçen zaman ve tasfiyeye ilişkin sorunlarda göz önünde bulundurulmalıdır. Tasfiye ancak müşteri açısından kötü niyet ve sahtekarlık söz konusu olduğu zaman en etkin çözüm olmaktadır.

\section{1- Teminatın Satış Kabiliyetinin Değerlenđirilmesi}

Bir teminatın satış kabiliyeti araştırılırken şu sorulara cevap aranmalıdır.

- Bu malın olası alıcıları kimlerdir?

- Bu alıcıların finansman ihtiyacı olacak midır?

- Alıcılara uygulanacak en etkin satış yöntemi nedir? (Doğrudan satış, açık arttırma, komisyoncu kanalı ile satmak gibi)

- Satış hangi sürede gerçekleşebilir?
- Zararı gidermek için nasıl bir fiyat saptanmalıdır?

\section{2- Gayrimenkul Tasfiyesi}

Teminat olarak alınmış gayrimenkullerin tasfiyesi özellikle fiyatlandırımaları açısından sorunlar yaratabilmektedir. Gayrimenkulun değeri bulunduğu mevkie göre farklılık göstermekte bu da değerinin saptanmasını güçleştirmektedir. Özel amaçlı inşa edilmiş binaları satma imkanları daha kısıtlı olmakta, özellikle içinde kiracı olan binaları satmak sorun yaratmaktadır.

\section{3- Stokların Tasfiyesi}

Stoklara rehin olmuşsa malların bitmiş ürün olmasına ve üretimin tamamlanmasına özellikle dikkat edilmelidir. Zira hammadde veya yarı bitmiş ürünlerin ekonomik değerleri yok denecek kadar azdır. Ancak malları bitirmenin maliyeti satışından elde edilecek gelirle karşılaştırılmalı aradaki fark olumlu ise üretim yapılmalıdır. Bitmiş ürünlerin müşterisi borçlunun halihazırdaki müșterileri, aynı iş kolundaki işletmeler veya mal alıp satan tüccarlar olmaktadır. Stoklarla ilgili diğer önemli bir sorun ise malların modasının veya geçerliliğinin yitirilmesidir ki bu aynı zamanda firmanı başarısızlığına yol açan faktörlerinde başında gelmektedir.

\section{4- Ticari Alacakların Tasfiyesi}

Teminat altına alınmış ticari alacaklar tasfiye süresince, önemli ölçüde değer yitirirler, bir müşterilerin böyle bir durumu fursat bilip ödeme yapmaktan kaçınırlar. Ayrıca firmanın sorunları da tahsil edilmeyen ticari alacaklara bağlanan paradan kaynaklanmıs olabilir.

\section{5- Makine ve Teçhizatın Tasfiyesi}

Bankalar çoğu zaman firmaların üretim araçlarını finanse ederler ve firmalarda bu araçiarla sağladıkları gelirleri borçlarını geri ödemek üzere kullanırlar. Ancak makine ve teçhizatın satılarak nakitte dönüştürülmesi bunların sadece belli amaçlarla ve sadece malların üretiminde kullanılması halinde güçleşmektedir. Ayrıca bu makinelerin yerlerinden demonte edilmesi ve taşınması da oldukça masraflı olabilmektedir.

\section{6- Banka Hesaplarına El Konma}

Sorunlu kredinin farkına varıldığı anda ilk reaksiyon çekli mevduat hesaplarına el koyarak firmanın borcunu bu hesaptan karşılamak olabilir. Ancak bu işlem firmanın finansal durumunu daha da kötüleştirebilir ve bankanın teminatları paraya çevirmesi durumunda teminatların değerinin düşmesinde dolayısıyla elde edebileceği fon miktarının azalmasına yol açabilir. Öte 
yandan bankanın fonlarının çekilmesine ve bankanın bu yoldan etkin bir şekilde parasını geri alma imkanının ortadan kalkmasına neden olabilir.

\section{II.4. Sorunlu Kredilerin Bankaya Maliyeti}

Bir banka kredi tahsis ederken daima çok yüksek ve çok düşük risk arasında bir ortayol bulunabilmelidir. Eğer banka çok düşük düzeyde risk üstlenmeyi tercih ediyorsa doğal olarak pazardaki önemli pek çok fırsatı elinden kaçıracaktır. Öte yandan pazarda kaçırılan firsatların maliyeti batan bir krediden çok daha az soruna neden olacaktır. Yüksek riskli ve sorunlu kredilerin bankaya olan maliyetleri şöyle sıralanabilir.

- Sorunlu kredilere tahsis edilen fonlar, daha yüksek getirili alternatif alanlara yönetilmeyecektir.

- Sorunlu krediler daha yakın ilgi ve takibi gerektireceğinden daha yüksek idari giderlere açacaktır.

- Sorunlu krediler yöneticilerin zamanlarını daha verimli alanlarda kullanımlarını engelleyecektir.

- Bankanın imajı ve piyasadaki ismi zedelenecek bu da bankanın büyümesini ve gelişmesini olumsuz olarak etkileyecektir.

- Sorunlu krediler hukuki konularda önemli ölçüde uzmanlığı gerektirmekte ve yüksek düzeyde hukuki giderlere neden olmaktadir.

- Sorunlu kredi miktarı yüksek olan bankalarda, düşük getiri ve sınırlı büyüme çalışanların moralini olumsuz olarak etkilemektedir.

\section{TÜRKIYE'DE TAHSILI GECIKMISS ALACAKLAR VE ALACAKLARIN TASFIYESINDEKI UYGULAMALAR}

Türk Mali Sistemi, 1980'li yıllarla birlikte dışa açık piyasa ekonomisine yönelik atılan adımların ve liberalizasyon sürecinin bir uzantısı olarak önemli bir yapı değişikliğine girmiştir. Atılan bu adımlar Türk Mali Sistemi içinde daha önceki dönemlerde de güçlü olan bankacılık sektörünün konumunun daha da güçlenmesine neden olmuş ve yapısal değişimin yönlendiriciliğini bu sektör ele geçirmiştir. Mali liberalizasyonun yasal altyapısının tamamlandığı 1980'li yılların ikinci yarısı ile birlikte artmaya başlayan kamu kesimi açıları ve bunların finansmanında yurtiçi kaynakların yetersizliği, yurtdışı tasarrufların ülkeye çekilmesini gündeme getirmiş ve özellikle 1990'ların ikinci yarısından itibaren bu süreçte bankacılık sektörü önemli bir rol oynamıştır. 1990 'lı yılların sonuna gelindiğinde mali istemde kontrolsüz gerçekleştirilen serbestleşme sürecinin yarattığı sıkıntılar ve bu sürecin ekonomideki yapısal zayıflıklar ile birleşmesi ekonomide makro yönetimi imkansız hale getirirken biriken kırlganliklar potansiyel bir finansal kriz olasılığını son derece yükseltmiştir. Bu nedenle 1999 yılının sonlarında IMF destekli bir istikrar programı uygulanmaya konularak biriken problemlere çözüm yaratılması amaçlanmıştır.

Uygulamaya konulan bu programın henüz başlangıç aşamasında ortaya çıkan tablo, Türk Mali Sisteminin uzun yıllardır alışkın olduğu yapının kırılmasına neden olmuş ve uzun yılların birikimi sıkıntılar sonuçta bu yapısal kırılmalar ile 2000 yılı Kasım ve 2001 yılı Şubat aylarında finansal bir krize dönüşmüştür. İlk krizde bankac1lık sektörü "faiz şoku" ile karşı karşıya kalırken ikinci krizde "döviz kuru riskine" maruz kalmıştır. Yaşanan bu şoklar finansal sistemde olduğu kadar reel sektörde de finansman yükünü artırmış ve reel sektörün finansal yükümlülüklerini yerine getirme kabiliyetlerine önemli ölçüde zarar vermiştir. Gelinen bu noktada bankacılık sistemi için "kredi risklerinden" kaynaklanan üçüncü bir şokun olasılığı son derece artmıştır.

Ekonomide ciddi daralma sinyallerinin yoğunlaştığı bir dönemde sorunların daha da büyümesini engellemek ve olası şokların ekonomide daha da büyük maliyetler yaratacağını göz önünde bulundurarak gerek kamu otoritelerine gerekse sorunun asıl muhatab taraflara ciddi sorumluluklar düştüğü bir gerçektir. Bu bağlamda, piyasa koşulları ve gönüllülük ilkeleri çerçevesinde ortak sorumluluk bilincini paylaşarak çözüm yollarının üretilmesi ve krizin koşullarının daha da ağırlaşmasının engellenmesi amacıyla bankacılık sisteminde tahsili gecikmiş alacakların kontrolde tutulması gerekmektedir.

\section{III.1. Uygulanan İstikrar Program ve Finansal Krizler}

1999 yllı sonunda uygulamaya konulan IMF destekli istikrar programı ile uzun yıllardır süreklilik gösteren enflasyonun kontrol altına alınması ve kamunun sürdürülemez hale gelen borç yapısının sürdürülebilir boyutlara indirilmesi temel hedefler olarak belirlenmiştir. Bu hedeflere uyumlu olarak ekonominin pek çok alanında ön görülen yapısal dönüşümlerin bir uzantısı olarak, bankacılık sisteminin güçlendirilmesi ve bankacılık düzenlemeleri de istikrar programında önemli bir yer tutmuştur. Programda bankacılık sisteminin güçlendirilmesine yönelik reformların üç boyutu bulunmaktadir.

- Bankacılık sektörü için dünya standartları ile uyumlu, güçlü ve güvenli bir yapının kurulması: Bu amaç için şu önlemler belirlenmiştir; etkin denetimin 
sağlanması, ihtiyathılı ilkelerinin geliştírilmesi ve şeffaflı̆̆ın artırılması,

- Problemli bankaların TSMF'ye devri,

- Kamu sektörü reformlunun bir parçası olarak kamu bankaları reformu.

Sektörün güçlendirilmesine yönelik olumlu adımlar atılmış olmasına karşın uygulamaya konulan istikrar programının temel nitelikleri ve bankacılık sektörünün uzun yıllardır birikmiş problemleri finansal sistemde kırılganlığın artmasına neden olmuştur.

Söz konusu istikrar programının finansal sistemde kırılganlığı artıran unsurları programın doğasında bulunan ve daha önceki ülke deneyimlerinde test edilmiş etkenlerdir. Uygulamaya konulan istikrar programı tasarlanmış şekli itibariyle klasik bir döviz kuru temelli enflasyonla mücadele programıdır. (Döviz Kuruna Dayalı İstikrar Programı, DKDİP), DKDİP tarzı programların diğer ülke uygulamalarından elde edilen tecrübeler doğrultusunda makroekonomik etkileri temelde üç noktada toplanmaktadir. Bunlar: iktisadi aktivitede ilkin hızlı bir canlanma ardından gelen durgunluk, yerel parada aşırı değerlenme ve ödemeler dengesi krizleridir. Tüm bu makroekonomik etkiler programi uygulayan ülkelerin finansal sisteminin içinde bulunduğu duruma, ekonomik koşulların yapısına ve dünya konjonktürüne bağlı olarak bankacılık sektörü üzerinde de etkili olmaktadır. Bu çerçeve içinde Türk bankacılık sistemi de kendi özgün yapısı içinde ele alındığında belirli noktalarda dünya uygulamaları ile paralellik gösteren etkilenmeler yaşamıştır.

Programın daha ilk günleri olan Ocak ayında bankacılık sektöründe makroekonomik etkiler bakımından ilk noktanın unsurları hissedilir hale gelmiştir. Bu tür programların ilk döneminde, beklenen enflasyona uyumlu olarak faiz hadlerinde gerilemeler yaşanabilmekte ve reel faiz oranları azalmakta hatta negatif düzeylere kadar inebilmektedir. Faiz oranlarında hızlı gerileme geçmiş dönemden elde bulundurulan yüksek faizli portföyler nedeniyle bir defaya mahsus servet etkisi yaratabilmektedir. Nitekim Türkiye'de de benzer bir durum programın ilk ayında yaşanmıştır.

DKDİP'nin ilk dönemindeki bir diğer olası etki ise, faiz oranlarındaki gerilemeye bağlı olarak yurtiçi tasarrufların gerilemesidir. Yurtiçi tasarruflardaki gerileme yurtdışı tasarruflarla ikame edilebildiği sürece ekonomideki canlılık devam edebilmektedir. Türk bankacılık sektörünün en önemli kaynak kalemi olan mevduatların 2000 yılı Kasım ayına kadarki gelişimi incelendiğinde bu noktada çarpıcı gelişmeler ortaya çıkmaktadır. Söz konusu süreç içinde TL mevduatlar reel gerileme gösterirken, yabancı para mevduatlar reel olarak artmıştır. Bu gelişmedeki belirleyici faktör ise programın başından ilan edilen kur hedefi ile gerçekleşen enflasyon rakamları arasında programin ilerleyen aylarında açıklanması bankacılık sisteminde yabancı para yükümlülük taşınmasını cazip hale getirmesidir. İstikrar programının açıklanması ile mali piyasalarda belirli bir güven ortamı yakalanmakla birlikte bu ortam bankacılık sisteminin kaynak yapısına yansımamıștır. 1999 yılı sonunda mevduatları vade yapısına bakıldığında üç aylık vadede yoğunlaşma oranı yüzde 35,7 iken, ilk krizin yaşandığı Kasım ayına kadar geçen dönemde aynı vade yapısındaki yoğunlaşma oranı yüzde 46,1 olarak gerçekleşmiştir. İlk finansal krize kadar geçen dönemde belirli aylarda vade yapısının 1 aya doğru kaydığı da ayrı bir gerçektir. $\mathrm{Bu}$ çerçeve içinde değerlendirildiğinde, bankaların kaynak yapısı kriz öncesi dönemde oldukça kısa vadede yoğunlaşmıştır.

DKDİP'nin makro etkilerinden ekonomik aktivitedeki canlanma sinyalleri 2000 yilının ilk aylarından itibaren Türkiye ekonomisinde hissedilmeye başlanmıştır. Uluslar arası gelişmelerin bankacılık sistemi üzerindeki doğrudan etkisi ise hızlı kredi genişlemesi şeklinde olmuştur. Özellikle 2000 yılının Ocak-Kasım döneminde faizlerdeki gerilemeye bağlı olarak artan tüketim talebi ve bunun sonucu olarak bankaların kullandırdığı tüketici kredilerindeki hızlı artış oldukça dikkat çekicidir. Bu noktadaki diğer ilginç bir nokta ise kullandırılan kredi kompozisyonu içinde TL kredilerin gelişimidir. Bankalar 2000 yll genelinde TL kredi kullandırımını YP kredilere tercih etmişlerdir. Krizin öncül koşullarının belirlenmesinde aşağıdaki tablodan elde edilebilecek diğer kilit nokta ise, bankaların, menkul değerler dağılımı içinde devlet tahvillerinin payı artarken hazine bonosu portföyünün ağırlığı azalmaktadır. Kısacası kriz öncesi dönemde bankacılık sektörü varlıklarını vade yapısı uzamaktadır.

DKDİP'nin ikinci etkisi olan yerel paranın aşırı değerlenmesi ve buna bağlı olarak cari işlemler dengesindeki bozulma programın ilk üç aylık döneminde kendini göstermeye başlamı̧̧ ve 2000 yılı sonunda söz konusu denge 9,8 milyar dolar açık vermiştir. Cari İşlemler dengesinin son beş yıllık en yüksek açığını vermesine karşın sermaye hareketleri ile bu açık büyük ölçüde kapatılabilmiştir. Sermaye hareketlerine kurumsal aracılık eden bankacılik sistemi de cari açıkların kapatılmasında kisa vadeli sermaye hareketleri aracılığıyla katkıda bulunmuştur. Kısacası bankacılık sistemi program öncesi dönemde geçerli olan koşullara uygun bir politika izleyerek açık pozisyon almaya hatta artırmaya devam etmiştir. Bu durumda temel faktör, programın başlangıcında faiz hadlerindeki hızlı gerilemeye karşın programın ilerleyen dönemlerinde bu gelişimin durması ile kur-faiz makasındaki genişlemenin yarattı̆̆ arbitraj imkanıdır. 
Kasım ve Şubat Krizlerinin Değerlendirmesi ve TGA'lar Üzerindeki Etkisi

Yukarıda özetlenmeye çalışılan gelişmeler bankacılık sisteminde olası bir krizin öncül koşullarını hazırlamıştır. Bankaların gerek faiz riski, gerekse döviz kuru riskine karşı artan duyarlılığı olası bir krizin zamanlaması dışında gerekli ip uçlarını özellikle 2000 yılının ikinci yarısından itibaren vermeye başlamıs ve nihayet Kasım ayında faiz riski ve 2001 yılı Şubat ayında kur riski realize olmuştur.

Yaşanan bu finansal krizlerin maliyeti Türkiye ekonomisi için oldukça yüksektir ve artarak devam etmektedir. Maliyetlerin bundan sonraki gelişimi ekonominin canlanma süresine girmesi ile doğrudan alakalıdır. Ekonominin canlanma evresine girişi ise gerek finansal sistemin gerekse reel sektörün rehabilitasyonu ve yeniden yapılandırılmasının hızına bağlıdır. Bu çerçevede gerek finansal kesimin bozulan mali dengelerinin daha da bozulmaması gerekse ekonominin üretken kapasitesinin korunabilmesi amacıyla finansal sistem üzerindeki tahsili gecikmiș alacakların kontrol altında tutulması ve bunların yeniden yapilandirılarak sistemden tasfiyesi ayrica bir önem kazanmaktadır. Bankacılık krizlerinin maliyetini artıran önemli faktörlerden birisi de geri dönmeyen krediler ve bunun sonucunda ödeme güçlügüne düşen reel sektör şirketleridir. Krizin ardından gelinin noktada bankaların tahsili gecikmiş alacaklarındaki dikkati çeken artış haklı bir kaygıya neden olmaktadır.

Tablo.1: Kriz Döneminde Çeşitli Göstergeler (\%)

\begin{tabular}{|c|c|c|c|c|c|c|}
\hline & \multirow{2}{*}{$\frac{1999}{\text { IV }}$} & \multicolumn{4}{|c|}{2000} & \multirow{2}{*}{$\frac{2001}{I}$} \\
\hline & & I & II & III & IV & \\
\hline \multicolumn{7}{|l|}{ Faiz Oranları } \\
\hline DİIBBS İhale Faizleri & 109.5 & 39,9 & 41,9 & 33,6 & 38,0 & 193,8 \\
\hline TL Mevduat Faizleri & 85.5 & 37,4 & 36,9 & 40,2 & 45,6 & 68,4 \\
\hline YP Mevduat Faizleri & 10,7 & 9,6 & 9,4 & 9,9 & 12,7 & 12,2 \\
\hline \multicolumn{7}{|l|}{ Mevduatların Dağılımı } \\
\hline TL Mevd/Toplam Mevd. & 54.9 & 51,0 & 50,7 & 49,7 & 55,9 & 52,5 \\
\hline YP Mevd/Toplam Mevd. & 45.1 & 49,0 & 49,3 & 50,3 & 44,1 & 47,5 \\
\hline \multicolumn{7}{|l|}{ Kredilerin Dağılımı } \\
\hline TL Kred./Top.Kred. & 57.1 & 61,6 & 65,3 & 67,5 & 67,2 & 59,8 \\
\hline YP Kred./Top.Kred. & 42.9 & 38,4 & 34,7 & 32,5 & 32,8 & 40,2 \\
\hline Tüketici Kred./Top.Kred. & 6,3 & - & 15,3 & 17,8 & 18,0 & 13,8 \\
\hline \multicolumn{7}{|l|}{ Menkul Değerler Cüzdanı } \\
\hline TL M.D.M.D. Cüzdanı & 66.0 & 71,0 & 71,0 & 68,4 & 68,3 & 65,7 \\
\hline TL Haz.Bon./TL M.D. & 37848 & 10,5 & 3,6 & 3,9 & 2,2 & 6,6 \\
\hline TL Dev. Tahvili/TL M.D. & 77.9 & 80,7 & 86,6 & 87,1 & 90,5 & 89,3 \\
\hline
\end{tabular}

Kaynak: DPT Temel Göstergeler, TCMB Haftalık Basin Bülten

Tablo.2: Kriz Döneminde Çeșitli Göstergeler (\%)

\begin{tabular}{|c|c|c|c|c|c|c|c|}
\hline & \multirow{2}{*}{$\frac{1999}{\text { IV }}$} & \multicolumn{4}{|c|}{2000} & \multicolumn{2}{|c|}{2001} \\
\hline & & I & II & III & IV & I & II \\
\hline \multicolumn{8}{|l|}{ TGS'ların Dağılımı } \\
\hline TL TGA/Y.İ. Kredileri & 11,3 & 11,8 & 11,2 & 10,5 & 10,9 & 13 & 17,8 \\
\hline YP TGA/Y.İ. Krediler & 0.7 & 1 & 1,1 & 1,1 & 1,3 & 1,4 & 2,7 \\
\hline Top. TGA/Y:I: Krediler & 12 & 12,8 & 12,3 & 11,6 & 12,1 & 14,4 & 20,5 \\
\hline \multicolumn{8}{|l|}{ Bankalara Göre } \\
\hline Kamu Ban./Y.İ. Krediler & 4,1 & 3,5 & 3,7 & 3,7 & 3,8 & 4,3 & 6,9 \\
\hline Özel Ban./Y.İ. Krediler & 7,7 & 8,9 & 8,2 & 7,5 & 8,0 & 9,7 & 13,1 \\
\hline Yabancı Ban./Y.İ. Krediler & 0,0 & 0,0 & 0,0 & 0,0 & 0,0 & 0,0 & 0,0 \\
\hline
\end{tabular}

Kaynak : TCMB Haftalk Basın Bülten 
Bankacılık sektörü açısından tahsili gecikmiş alacakların kontrol altında tutulması ne kadar önemliyse tablonun diğer tarafı yani reel sektör açısından da sorunun çözüme kavuşturulması en az o kadar önemlidir. -Reel sektörün mali durumu incelendiğinde, krizin ardından, banka kredilerinin yabancr kaynaklar içindeki artan ağırlığının önemi dikkat çekmektedir. Buna paralel olarak banka kredileri ile finanse edilen varlık miktarı da artmaktadır. Uzun yıllardır içselleşen enflasyonist ekonomik ortam özel firmaların yabancı kaynak yapısının kısa vadede yoğunlaşmasına neden olmuştur.
$\mathrm{Bu}$ veriler 1 șığında ortaya çıkan genel tablo gerek bankacılık sektörünün gerekse reel sektörün ekonomik ve mali koşulların daha da ağırlaşmasının engellenmesi bakımından ortak çıkarlara sahip olduğunu göstermektedir. Bu nedenle tahsili gecikmiş alacaklarda sistemden ayıklanırken tarafların ortak çıkarlarına hizmet edecek çözümlerin ortak sorumluluk bilinci ile belirlenmesinin önemi artmaktadır.

Tablo.3: Özel Firmaların Kaynak Yapısına İlişkin Göstergeler

\begin{tabular}{|l|c|c|c|c|c|c|}
\hline & 1995 & $\mathbf{1 9 9 6}$ & $\mathbf{1 9 9 7}$ & $\mathbf{1 9 9 8}$ & $\mathbf{1 9 9 9}$ & $\mathbf{2 0 0 0}$ \\
\hline Kaynak Yapısı & 66,6 & 68,0 & 68,5 & 67,8 & 70,8 & 68,8 \\
\hline Yabancı Kaynaklar & 33,4 & 32,0 & 31,5 & 32,2 & 29,2 & 31,2 \\
\hline Özkaynaklar & \multicolumn{7}{|l|}{} \\
\hline Borc Yapısı & 78,6 & 78,7 & 73,8 & 73,4 & 72,1 & 71,7 \\
\hline K.V. Yabancı Kaynaklar & 21,4 & 21,3 & 26,2 & 26,6 & 27,9 & 28,3 \\
\hline U.V. Yabancı Kaynaklar & & & & \\
\hline Finansal Oranlar & 33,4 & 32,0 & 31,5 & 32,2 & 29,2 & 31,2 \\
\hline Özkaynalar/Aktif Top. & 24,0 & 26,5 & 28,1 & 28,0 & 29,4 & 28,2 \\
\hline Banka Kred./Aktif Top. & 35,6 & 38,7 & 40,9 & 41,3 & 41,5 & 41,0 \\
\hline Banka Kred./Yab. Kaynaklar &
\end{tabular}

\section{III.2. Türkiye'de Tahsili Gecikmiş Alacakların Tasfiyesi ile IIgili Kurumsal Uygulamalar}

Türkiye'de TGA'ların tasfiyesi ile ilgili ayrı bir kurumsal yapılanma bulunmamaktadır. Bankacılık Denetleme ve Düzenleme Kurumu (BDDK) yapılanması içerisinde- Tahsilat Dairesi, İştirak Dairesi, Gayrımenkul Dairesi TGA'ların tasfiyesine yönelik çalışmakta olan birimler olup BDDK bünyesindeki kredilere yönelik faaliyet göstermektedir. TGA'ların tasfiyesine yönelik olarak 2002 yılı başında bir VYŞ'nin kurulmasına karar verilmiştir. Bu amaçla 31.12.2002 tarihi ve 4743 sayılı bir kanun ile bankalar, özel finans kurumları ve diğer mali kurumların alacakları ile diğer varlıklarını devralarak yönetmek üzere kuruluş ve faaliyet esasları Bankacılık Düzenleme ve Denetleme Kurulu tarafindan belirlenecek varlık yönetimi şirketlerinin kurulabilmesi öngörülmüştür. Ayrıca, TMSF bu şirketlere, şirket sermayesinin yüzde yirmisini aşmamak kaydıyla katılmaya yetkili kılınmıştır.

VYŞ kurulmasına ilişkin olarak hazırlanan ve yaklaşık 6 aylık bir hazırlık/kuruluş süreci içeren bir eylem takvimi ana faaliyetler itibariyle 2002 yılı Mart ayında açıklanmıștır. VYŞ'nin oluşturulmasın ve tam olarak işlerlik kazanmasının genellikle 7 ile 15 aylık bir süre gerektirdiği öngörülmüştür, şirketin kredi devralmaya başlayarak tam bir işlerlik kazanması büyük ölçüde uygulayacağı değerleme ve fiyatlama yöntemine bağı olacağı belirtilmiştir. Şirket Eylül 2002 itibariyle henüz faaliyete geçmemiştir. 
Tablo.4: Varlık Yönetimi Şirketi Kurulması Hakkında Eylem Takvimi

\begin{tabular}{l}
\hline FAALIYET \\
\hline I. Koordinasyon Komitesinin Belirlenmesi: VYŞ kurulması sürecinde TMSF tarafından yürütülecek \\
faaliyetlerin gerektiği gibi, düzenli, tutarlı ve zamanında gerçekleştirilebilmesi amacıyla, yönetim ve \\
koordinasyondan sorumlu 5-10 kişilik bir komite oluşturulacaktır. Bu komitenin VYŞ'de TMSF'yi temsilen \\
görevlendirilecek insan gücünün çekirdeğini oluşturması amaçlanmaktadır. \\
\hline II. Şirket Modelinin Tasarlanmaya Başlanması: Kurulacak VYŞ'nin kendisinden beklenen işlevleri etkin \\
bir biçimde yerine getirebilmesi için uygun bir şekilde modellenmesi gerekmektedir. Bu çerçevede şirketin; \\
-Hukuki statüsünün, \\
-Ortaklık yapısının, \\
-Organizasyon yapısının, \\
-Görev, yetki ve sorumluluklarının, \\
-Müşterilerinin kim olacağının, \\
-Ne tür varlıkların devralınması ve yönetimi ile uğraşacağının, \\
-Eğer gerekli görülüyorsa, tabi olacağı gözetim çerçevesinin belirlenmesi gerekmektedir. \\
Kurulacak șirketin tasarımı, sektörün ve potansiyel yatırımcı kuruluş̧arın yaklaşımları da göz önünde \\
tutularak, takvimin daha ileri aşamalarında kurum içindeki görüş alışverişlerini, diğer ülke tecrübelerinin \\
incelenmesini, danışmanlık hizmetinden yararlanılmasını içeren bir süreç dahilinde yürütülecektir.
\end{tabular}

III. Reel ve finansal sektör temsilcileri ile toplantılara başlanması: başta TOBB, TÚSIAD TBB olmak üzere, reel ve finansal sektörün önde gelen örgütlerinin, mümkün olan her aşamada, sürece katılımı sağlanacaktır. Bu katılım, reel ve finansal sektörün sistemden beklentilerini modele yansitarak sistemin daha sağlıklı bir biçimde oluşturulmasını ve sisteme yönelik desteğin artınlmasını sağlayacaktır. Bunun yanı sıra özellikle reel sektörden şirkete ortak olabilecek potansiyel yatırımcıların belirlenebilmesi ve bunlarla diyalog sürecinin başlatılabilmesi kolaylaştırılacaktır.

IV. Diğer ülke Tecrübelerinin yerinde incelenmesi: Oluşturulan Komitenin dört üyesi, diğer ülkelere ait başarıl1/dikkat çekici VYŞ tecrübelerini yerinde incelemek üzere, 2 ila 3 ay süre ile yurtdışına staja gönderilecektir. İncelemeler özellikle varlık havuzlarının hazırlanması, pazarlama teknikleri ve sistemin genel işleyişi üzerinde yoğunlaşacaktır. bU kapsamda, gerek benimsedikleri kapsamlı ve profesyonelce yaklaşımlar ve gerekse elde ettikleri nisbi başanlar nedeniyle finans dünyasında ilgi odağı haline gelen $\mathrm{G}$. Kore'ye (KAMCO) ve Malezya'ya (Danaharta) ikişer eleman gönderilecektir. Sözkonusu staj imkanı nedeniyle, gönderilecek Komite üyelerine VYS'de asgari bir yıl çalışma şartı getirilecektir.

V. VYŞ'nin tasarlanması konusunda danışmanlık sağlanması: VYŞ'nin yapısının ve işleyiş sisteminin tasarlanması sırasında, özellikle uluslar arası tecrübelerden azami derecede faydalanılabilmesini teminen, IMF veya Dünya Bankası kanalıyla VYŞ konusunda tecrübeli bir danışmandan, Nisan ve Haziran aylarının ilk yarısında ikișer hafta süreyle teknik yardım alınacaktır.

VI. Ulusal ve uluslar arası kuruluşlar ile toplantılar: Başta IMF olmak üzere, uluslar arası kuruluşlar ve yatırım firmaları ile bir dizi toplantı yapılacaktır. Bu toplantının amacı kurulacak VYŞ konusundaki görüş ve beklentilerin belirlenmesidir. Toplantılarda bu kuruluşların özellikle VYŞ'nin ortaklık yapısında ve yönetiminde yer almak ve VYŞ ile ortak iş yapmak konularındaki yaklaşımları netleștirilecektir.

VII. Anasözleşme taslağınun potansiyel yatırımcılara gönderilmesi: Kurum içinde oluşturulan ve potansiyel yatırımcılarla mutabık kalının esaslar çerçevesinde şekillenen anasözleşme taslağı, ilgilenen yatırımcilara gönderilecektir.

VIII. Anasözleşme taslağının kesinleştirilmesi: Potansiyel yatırımcılarla yapılacak bir dizi toplantı neticesinde anasözleşme taslağ kesinleşecektir.

Nisan/May1s

2002

TAKVIM

Mart 2002

Nisan 2002

IX. VYS’'nin yönetim Kurulunun belirlenmesi: Ortaklık yapısı ve buna uygun yönetim kurulu kesinleştirilecektir

X. VYS'nin dizaynı ve kurulus prosedürünün belirlenmesi:Yönetim kurulunun görevlendireceği bir komite ya da danışmanlık şirketi, daha önceki aşamalarda ortaya çıkan ve üzerinde mutabık kalınan esaslar çerçevesinde, VYŞ'nin yapısına, faaliyet esaslarına ve kuruluş prosedürüne ilișkin detayları belirleyecektir.

XI.VYŞ'nin kuruluşu: Bir önceki aşamada detaylanı belirlenen kuruluş ve faaliyet esaslan çerçevesinde Temmuz 2002 VYŞ'nin kuruluşu gerçekleștirilecektir.

XII. VYŞ tarafından kredi satın alınmasına bașlanması: Fiili olara kredi devirleri VYŞ'nin varlıklanı Ağustos 2002 değerleme ve fiyatlama politikası ile çok yakından ilgilidir. Ömeğin VYŞ'nin sabit bir iskonto değeri üzerinden alım yapması süreyi kısaltırken, kredilerin piyasa değerini tespite yönelik olarak detaylı inceleme / değerleme yapması, VYŞ’nin kredi alımına girişerek tam olarak işlerlik kazanması için gerekli süreyi uzatacaktır.

Kaynak:http://www.bddk.org.tr 


\section{SONUÇ}

Ödemeler sisteminin en önemli parçasını oluşturan bankacıllk sektörü, istikrarsız ekonomik yapı, yetersiz yasal ve idari düzenlemeler, denetim eksikliği, risk yönetiminde başarısızlıklar vb. nedenlere bağlı olarak, zaman zaman yüksek maliyetli krizlerle karşı karşıya gelebilmektedir. Karşılaşılan bankacılık krizlerinin ödemeler sisteminde rahatsızlıklara neden olması, krizin sadece bankacılık sektörü ile sinırlı kalmamasına ve reel sektör üzerinde de olumsuz yansımalar göstermesine neden olmaktadır. Üretimin finansmanını sağlayacak kaynakların akışında yaşanan sıkıntıların reel sektör ve ekonominin geneli üzerinde yarattığı tahribat bankacılık sektöründe başlayan krizin niteliğini değiştirebilmekte ve krizin derinliği ile maliyetini arttırabilmektedir.

Krizin boyut ve niteliğini etkileyebilecek faktörlerin başında ise ekonomideki tüm birimlerin yükümlülüklerini yerine getirme kabiliyetindeki gerileme gelmektedir. Nitekim krizle birlikte makroekonomik değişkenlerdeki (özellikle faiz ve kur) istikrarsız yap1 bankaların mali bünyelerinde olduğu kadar reel sektör şirketlerinin mali yapılarında da bozulmalara neden olabilmektedir. Sonuçta bankacılık sisteminde TGA stoku hızla artarken, şirketler kesimin kurumsal borçları ifa edilemez boyuta ulaşabilmektedir. Söz konusu durum şirketler kesiminde yoğun iflaslarla karşılaşılmasına neden olabilmekte, benzer gelişmeler bankacılık sisteminde de yaşanabilmektedir.

Bankacılık sisteminde başlayan ve ekonominin geneline yayılan krizin neden olacağı maliyetlerin mümkün olan en alt düzeyde tutulabilmesi, bahsi geçen TGA stoku ve kurumsal borçların uygun politika ve stratejiler ile en kısa sürede çözüme kavuşturulabilmesine bağlıdır.

Nitekim bankacılık krizleri yaşamıș diğer ülke uygulamalarına da bakıldığında maliyetlerin paylaşımına yönelik politikalar ve yasal tedbirler içerisinde bankacıllk sektöründen TGA'nın tasfiyesinin ve kurumsal borçların yapılandırılmasının ağırlıklı bir yer tuttuğu dikkati çekmektedir.

Bankacillk sisteminden TGA' in tasfiyesi edilmesi ve şirket borçlarının yapılandırılarak ekonomideki üretken kapasitenin korunmasına yönelik temelde iki politika seçeneği bulunmaktadır. Bunlardan ilki bankacılık sisteminden TGA'in belirli bir çerçeve içinde devralınarak bankaların mali yapısının kısa süre içinde iyileştirilmesine imkan sağlayan Varlık Yönetim Şirketi uygulamas1, diğeri ise bankalar ile şirketlerin belirli bir platform üzerinde piyasa mekanizması içinde ve gönüllülük esasına göre bir araya gelerek şirket borçlarının yapılandırılmasını sağlayan ve genel olarak Londra Yaklaşımı olarak bilinen kurumsal borç yapılandırma politikasıdır.
Varlık Yönetim Şirketi uygulaması bankacılık sisteminden sorunlu varlıkların alınarak bankaların asli görevi olan mevduat toplama ve kredi verme fonksiyonuna odaklanmasını sağlamayı amaçlayan bir politika seçeneğidir. Bu şekilde bir yandan bankaların krize birlikte zayıflayan mali yapıları güçlendirilirken bir yandan da zayıflayan makroekonomik yapının yoğun şeklide ihtiyaç duyduğu kaynak akışı rahatlatilabilmektedir.

Bankacrlık krizleri yaşamış diğer ülkelerin tecrübelerine bakıldığından iki tür Varlık Yönetim şirketi uygulaması dikkat çekmektedir. Bunlardan ilki; bankanın iştiraki şeklinde kurulan ve sorunlu varlıkların bu iştirake aktarılmasını içeren Varlık Yönetim Şirketi uygulaması, diğeri ise tüm bankacılık sistemine hitap edecek şekilde çalışan ve genellikle devletin sahipliğinde olan Varlık Yönetim Şirketi uygulamasıdır.

İlk uygulama şirketlere ilişkin kurumsal bilgilerin bankadan uzaklaşmamasını sağlaması ve devletin doğrudan katlanacağı yükü azaltmasına karşın, krizle birlikte mali yapısı zayıflamış bankaların ayrı bir mali iştirak kurması genelde mümkün olmamaktadır.

Merkezi Varlık Yönetim Şirketi olarak tanımlanan devlet sahipliğindeki uygulama ise devletin katlanacağ doğrudan maliyetleri artırması ve şirketlere ait kurumsal bilgilerin bankalardan ayrılması sonucu olaşabilecek bilgi kaybına karşın, bankaların mali yapıların hızlı bir şekilde düzeltilmesi, devralınan varlıkların belirli bir havuz içinde toplanarak oluşabilecek ölçek ekonomilerinden yararlanılabilmesi ve sistemdeki tüm bankaların faydalanabileceği bir yapının oluşturulabilmesine imkan sağlaması açısından, özellikle son dönemde yaşanan banka krizlerinin ardından tercih edilen bir politika aracı olarak dikkati çekmektedir.

Söz konusu Varlık Yönetim Şirketi modellerinden hangisinin tercih edileceği karşı karşıya kalının krizin, boyut, ülkenin ekonomik koşulları, gelişmiş bir mali piyasanın varlığı vb. faktörlere bağlıdır.

2000 yılı kasım ve 2001 yılı Şubat aylarında yaşanan krizlerin ardından ülkemizde de bankacılık sektöründe TGA stokunun hızlı arttığı ve reel sektörün borçlarını ödeme kabiliyetini önemli ölçüde yitirdiği bir dönemde TGA'ın tasfiyesine yönelik kurumsal yapılanma oldukça önem kazanmıştır. Ancak TGA stokunun gelişimi izlendiğinde de gecikildiği ve hukuksal altyapısı hazırlanmış olan Varlık Yönetim Şirketi ve kurumsal borçların yeniden yapılandırılması uygulamalarına bir an önce geçilmesi gerekmektedir.

Diğer ülke uygulamaları dikkate alındığında TGA stokunun bankacılık sisteminden tasfiyesinde ve kurumsal borçların yapılandırılmasında ikili bir yapının kurulması uygundur. $\mathrm{Bu}$ çerçevede kurulacak Varlık Yönetim 
Şirketi'nin sorunun çözümüne tarafların katılımını sağlayacak ve maliyet paylaşımında sorunun muhatapları arasında adaleti gözetecek şekilde faaliyet göstermesi önemlidir.

Özel kanun ile kurulan Varlık Yönetim Şirketinin profesyonel esaslara göre yönetilecek olması benzer ülke uygulamaları ile ötüşmektedir. Ancak kanunda belirtilmemiş ve yönetmelik ile belirlenecek olan Varlık Yönetim Şirketinin hizmetlerinden yararlanacak bankaların sorumlulukları ve hangi koşullarda bu hizmetten faydalanabilecekleri açıkça belirtilmelidir. Ayrıca, bu kanunla Varlık Yönetim Şirketi tarafından devralınacak varlıkların neler olduğu ve önceliğin hangi varlıklara verileceği de açıklığa kavuşturulmalıdır.

TGA'nın ve kurumsal borçların yapılandırılmasına önerilen ikinci yapı olan "Londra Yaklaşımı" ile ilgili çerçeve oluşturulmuş durumdadir. Her ne kadar Çerçeve anlaşmasının Reel sektör desteği ile hazırlanmış olsa da şirket borlarının yapılandırmaya yönelik çalışmalarda koordinasyonu sağlayacak birimin TBB tarafindan atanacak olması ve kamu ve reel sektöründen mevcut yapı içerisinde bulunmaması diğer ülke uygulamalarından ayrilan bir husustur. Bu tür bir kurulda reel sektör, kamu ve bankacılık sektörünün eşit ölçüde temsil edilmesinin daha uygun olacağı diğer ülke uygulamalarından anlaşılmaktadır.

Sonuç olarak dünya tecrübelerinden de görülebileceği gibi TGA' nın ve kurumsal borçların krizlerle zayıflamış ekonomik yapı üzerinde yaratacağ olumsuzluklar ancak bu şekilde izlenecek kapsamlı ve birbirini destekleyen politikalarla engellenebilmektedir.

\section{YARARLANILAN KAYNAKLAR}

[1] SEVAL, B., Sorunlu Krediler, TBB Eğitim ve Tanıtım Grubu Seminer Notlar1, Mart 2000, ss.1,2.

[2] IYYIGÜN, T., Kredilendirme Teknikleri, TBB Eğitim ve Tanıtım Grubu Seminer Notları, Şubat 1998, ss.24,26.

[3] BODUR, V.; BODUR, C.., Kredi Risk Yönetimi ve Kredilendirme Teknikleri, TBB Yayınları, Haziran 1999. s.36.

[4] AKTAŞ, M., Sorunlu Kredilerde Erken Uyarı AraçlarıÇözümleri, TBB Eğitim ve Tanıtım Grubu Seminer Notları, Aralık 2000. ss.12-15.

[5] SEYAL, B., Kredilendirme Süreci ve Kredilendirme Yöntemleri, İ.Ü. Muhasebe Enstitüsü Yayınları No:59, 1990, ss.10, 330.

[6] ERSEL, H., Turkish Baking Under the Economic Stabilization Program, Ocak 2001. s.4.
[7] İstatistikler, TCMB Haftalık Basın Bültenlerinden derlenmiştir

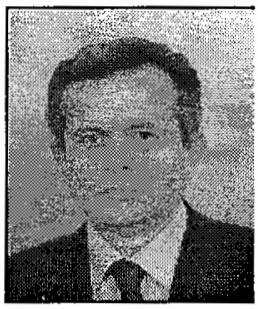

Hasan SELCUK

Marmara Üniversitesi

Hukuk Fakültesi

Haydarpaşa Kampüsü - İSTANBUL

Tel: +902163498402-181

hasanselcuk@hotmail.com

Hasan SELÇUK has Ph.D. of Labor Economics and Industrial Relations at Istanbul University Social Sciences Institute. He is Associate Professor at Marmara University. His research areas are economics of Middle East and central Asian countries, international finance, banking and finance.

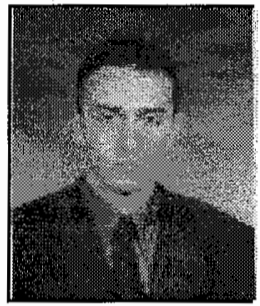

\section{Adem DARICI \\ Denizbank AS \\ Bakurköy Şubesi \\ Bakırköy - ISTANBUL \\ ademdarici@hotmail.com}

Adem DARICI received his master degree from Marmara University Banking and Insurance Institute. He is marketing professional at Denizbank AȘ. Bakırköy Branch. His interest area is banking. 